\title{
AZ ORIGO ÉS A HVG CIKKEINEK SZÖVEGELEMZÉSE A FÖLDRAJZOKTATÁS SZEMSZÖGÉBŐL
}

CONTENT ANALYSIS OF ARTICLES PUBLISHED IN ORIGO AND HVG FROM THE PERSPECTIVE OF GEOGRAPHY TEACHING

HOMOKI ERIKA

Eszterházy Károly Egyetem, Pedagógusképző Központ

homoki.erika@uni-eszterhazy.hu

\begin{abstract}
Due to the transformation of conditions in education, knowledge and process of learning is reassessed. Inthe past century owning information was asset for the individual but it was accessible only for few people. This situation was changed fundamentally owing to the evolvement of information society. In the educationsystem of the digital age emphasis should not be placed on how to access information but on teaching thecritical use of information, transform it to knowledge and reach the goals of education and development ofcompetences. In my research I systematized the geographical information of the most used internet portal (Origo) and a professional journal (HVG) and then compared them with the key competences and knowledge appearing inthe operative regulations of public education. I assessed the results to detect the extent of overlaps betweenthe content of teaching and ordinary information and whether it is sufficient for understanding ordinaryinformation.
\end{abstract}

Keywords: content analysis, geography content, curriculum, geography teaching

\section{Bevezetés}

A tudományokban és a társadalomban bekövetkező változások az oktatásban is kikényszerítik a tartalom és a módszerek átalakítását. Bár az átadandó ismeretek a múlt század elejétől a közgondolkodás kereszttüzében állnak, az információs társadalom mai formájának megjelenésével kulcskérdésnek tünik, hogy mi szükséges a társadalmi igényekhez legjobban igazodó oktatás megteremtéséhez. A múlt század elején még az általános műveltség volt a tananyag kiválasztásának szempontja, míg az információ jelentőségének és hozzáférésének megváltozásával, napjaink elvárása szerint a társadalom számára hasznos ismereteknek és képességeknek kellene meghatározniuk a tantárgyi tartalmat a közoktatásban. Ez a szemlélet igazán a rendszerváltás után erősödött fel, amelyhez a Nemzeti alaptantervet és a Kerettantervet is igyekeznek hozzáigazítani.

Kutatómunkám során ehhez a szemléletváltáshoz szerettem volna hozzájárulni, mégpedig a társadalom számára megismerhető információforrások tartalomelemzésével. Úgy gondolom, hogy a tanulók szövegértési problémái mögött gyakran az oktatási 
szövegekben elöforduló fogalmak ismeretlensége, illetve a szövegelemek közötti összefüggések felismeréséhez szükséges kompetenciák hiánya áll. Ma divatos a porosz típusú és a liberális oktatási rendszer szembeállítása, pedig az alapismeretek stabil tudása mindkét oktatási szemléletben megtalálható. Kérdés az, hogy az iskolában közvetített tudás mennyire párhuzamos a köznapokban megjelenő földrajzi ismeretekkel. Ezért vizsgálatom tárgyaként két választott internetes médium (az Origo és a HVG) szövegelemzési eredményeit mutatom be összehasonlítva az érvényes tantervi dokumentumokkal.

\section{Módszer és mintavétel}

Mint fentebb jeleztem, a hétköznapokban használt földtudományi-földrajzi fogalmak ismeretének felméréséhez a tartalomelemzés módszerét választottam. Ide tartoznak azok az eljárások, ahol az olvasás során a szöveg mögöttes tartalmából vonunk le elsődlegesen nem látható következtetéseket (AntAL L. 1976, Krippendorff, K. 2004). A módszerről részletesebben Krippendorff, K. (2004) és Lengyel Molnár T. (2011) munkáiban olvashat többet az érdeklődő. A kvalitatív tartalomelemzés számítógépes támogatása az 1980-as években jelent meg. Napjainkra közel 50 darab e célt szolgáló szoftver létezik. Az adatállomány kezeléséhez a német fejlesztésű Atlas.ti kódoló szoftvert használtam, mert az a fájlformátumok széles skáláját képes kezelni: HTML, szöveg, videó- és hangállományok elemzése is megoldható vele.

A mintavételi eljárás keretét az írott, online média adta, amelyből többlépcsős szubjektív nem valószínűségi mintavételi eljárással (BABBIE, E. 2001) választottam ki a vizsgált lapokat. Az adatbázist a kiválasztott médiumok szövegeinek adatátalakításával nyertem. Az elemzés egysége a szó lett, a szavakat földrajzi tartalmuk alapján kategorizáltam. Tekintve, hogy az írott sajtó olvasottsága az utóbbi évtizedben erőteljesen lecsökkent (Melles K. 2009), az olvasottsági adatok alapján szúkített közéleti lapok halmazából a HVG és az Origo online változatát választottam. A HVG vizsgálatom idején a bulvárlapok után a legolvasottabb közéleti-gazdasági hetilap volt (TERESTYÉNI T. 2008). Ugyan nem földrajzi szaklap, de információit gyakran használják földrajzi képzések és társadalomföldrajzi kutatások során. Az Origo - a 2014 januári átlagadatok alapján - a száz leglátogatottabb hazai weboldal közül a harmadik (a hírportálok között első) helyen szerepelt 579000 fös napi egyedi látogatószámmal (SzuHi A. 2014).

A vizsgált lapszámok a 2000.01.01. és 2012.12.31. közötti időszakot ölelték fel. Ez érintette a tantervi változások időszakát is (például kétszintü érettségi bevezetése), továbbá 
a közéletben az ország helyzetét befolyásoló események zajlottak (például európai uniós csatlakozás). Az előbbi változások nyomon követése a közoktatási tartalom módosulásával járt, utóbbi eseményekről pedig azt feltételeztem, hogy a médiumokban megjelenő földrajzi tartalmak eloszlását is befolyásolja. A minta nagyságát a pedagógiai kutatásokban elfogadott 95\%-os konfidencia intervallum mellett, 5\%-os hibahatárt szem előtt tartva számoltam ki egy mintaméret kalkulátor segítségével (Sample Size Calculator, 2012). Így az Origo felületéröl, ahol naponta új hírek jelennek meg, összesen a 365 napnyi hír szövegét vizsgáltam meg. A HVG hetilap esetén 244 lapszámot dolgoztam fel, tehát összesen $600 \mathrm{db}$ lap teljes szövegét elemeztem az Atlas.ti szoftver segítségével, mely a vizsgált időszak teljes lapszámának (5412 db) 11\%-a.

\section{Adatbázis, feldolgozás}

Az adatokat az Atlas.ti szoftverben lefuttatva, a 813576 sorból álló 17007521 darabos szószedetet Excel fájlba exportáltam. A kigyüjtött szóstatisztikából redukáltam az adatkészlet földrajzi-földtudományi tartalmú részét. A szavak elemzése során a háttérszöveg információtartalmát nem vizsgáltam, csupán a digitális szószedet fogalmait kategorizáltam. Az adatbázis korrekciója során kiszűrtem bizonyos fogalomtípusokat, amelyek tovább növelhették volna a földrajzhoz is köthető fogalmak adatmennyiségét. Így többek között - oktatási használatuk ellenére - kimaradtak az ágazati földrajzhoz tartozó márkanevek és cégnevek, bár néhány, a magyar köztudatban stabilan megtalálható hétköznapi márkát, amelyek akár érettségiben is előfordulhatnak (például Opel, Suzuki) megtartottam. Nem vettem figyelembe a fajneveket, amelyek szövegkörnyezettől függően, gyarapíthatták volna a földrajzi övezetesség témakörét is. Kizártam a többségében társadalomföldrajzba tartozó mozaikszavakat, így kimaradtak a politikai pártok, cégek, intézmények stb. megnevezései. Egységesen régió kategóriába soroltam minden, a település és az ország közötti területi szerveződési szintet jelölő fogalmat (például tagországok, szövetségi államok, járások, megyék). Az ország, régió, település esetén az elsődleges társadalmi topográfiai tartalmat vettem figyelembe, nem mérlegeltem a szövegkörnyezetüket.

A tantervek szövegében sokszor csak a halmazképző fogalom szerepel. A bányászat például használt, de nincs a kulcsfogalmak között a szénbányászat. Ezeket „nincs benne a tantervben” kategóriaként jelöltem, mert így a pedagógus döntése, hogy mit tanít meg az adott témakörből. A több szavas szóösszetételek sem jelennek meg az elemezhető fogalmak között. Például a Bükki Nemzeti Park 8, vagy a világörökségi helyszínek 
162 darabos elöfordulása azt bizonyítja, hogy a természetföldrajzi adatbázis is nagyobb lehetne a kódolatlan adatok alapján. A népességcsoportoknál csak azon országok népeit hagytam kontinenshez kapcsolva, ahol az ország legalább az érettségi topográfiai névanyagban említést kapott, mert akkor, igaz esetlegesen, a népességet is megnevezhetik a tanítás során. Minden népcsoportot a társadalomföldrajzi fóágba tettem, hiába jelölnek regionális helyeket is (például kínai lehet személy és termék is). Végül a forint, euró, dollár és frank kivételével a valutákat töröltem az adatbázisból, mert a tanterv csak a valuta fogalmát várja el megtanítandónak.

A kapott adatbázist a szószedet azonos tövủ szavainak, szószerkezeteinek összevonásával véglegesítettem. Ezután a nyers adatsorból elsődleges szüréssel kigyüjtöttem a legalább 0,01\%-os elöfordulási gyakoriságú fogalmakat, és csak ezeket vetettem össze a kerettantervekkel és az érettségire kiadott topográfiai névanyaggal. Nyilván a teljes adatbázis kicsit módosította volna az arányokat. Ezután az eredeti, teljes fogalmi adatbázist három fö ágba és egy tudománycsoportba soroltam a földrajz tantárgyi megjelenésének megfelelően, ezt követően pedig a fogalmakat további alcsoportokba. A kategóriákat az új kerettantervi témakörök [51/2012. (XII. 21.) EMMI Rendelet. 2012], szakirodalmak (VoFKORI L. 2003), valamint az MTA Földrajzi Bizottságok állásfoglalása alapján alakítottam ki (1. táblázat). Az elsődleges tantervi témakörök közül kiemelt regionális földrajzot fö tudományágként szerepeltettem. Ilyen esetekben másodlagosan jelenítettem meg a természetvagy társadalomföldrajzi beosztást. Az táblázat utolsó két sorában szereplö, a három fö kategóriába nem besorolható (pl. a globális problémákhoz vagy a tudománytörténethez

\begin{tabular}{|c|c|c|}
\hline Természetföldrajz & Társadalomföldrajz & Regionális földrajz \\
\hline $\begin{array}{l}\text { Csillagászat és ürkutatás } \\
\text { Térképészet } \\
\text { Földtan } \\
\text { Felszínalaktan } \\
\text { Talajföldrajz } \\
\text { Légkör és meteorológia } \\
\text { Vízburok } \\
\text { Földrajzi övezetesség, } \\
\text { táj- és életföldrajz } \\
\text { Környezet- és természetvédelem }\end{array}$ & $\begin{array}{l}\text { Népességföldrajz (vallás- és etnikai földrajz is) } \\
\text { Településföldrajz } \\
\text { Politikai földrajz és közigazgatás } \\
\text { Általános gazdaságföldrajz, közgazdaság } \\
\text { Ágazati gazdaságföldrajz }\end{array}$ & $\begin{array}{l}\text { Természetföldrajz } \\
\text { Társadalomföldrajz }\end{array}$ \\
\hline \multicolumn{3}{|c|}{ Globális problémák } \\
\hline
\end{tabular}

1. táblázat. A médiából gyüjtött fogalmak besorolásának rendszere 
kötődő) fogalmak csak a teljes minta 0,2\%-át képviselik, de jelezni kívántam, hogy a tudományterületi megnevezések média-előfordulása miatt fontos ezek közoktatási definiálása.

\section{Eredmények}

Az adatbázisban a földrajzi fogalmak aránya a teljes mintára (17 millió) vetítve 9,88\%, amely 1681308 szót tartalmaz, és ez 23028 szótőhöz köthető. Az összegyüjtött földtudományi fogalmak (9,88\%) közel fele-fele általános (53,75\%) és regionális $(46,25 \%)$ csoportba sorolható (3. ábra). A három fó részterülethez tartozó fogalmak médiaelőfordulási gyakorisága jelentős eltérést mutat a természetföldrajz $(-32,83 \%)$ és társadalomföldrajz (+41,3\%) tantervi arányához képest (1. ábra). A tantárgyi reform során ez jelzésértékü a két témakör ismeretanyagának felülvizsgálatához. Azt azonban figyelembe kell vennünk az eredmény értelmezésekor, hogy a HVG gazdasági jellegü lap, ami bizonyíthatóan torzítja a témakörök arányát, míg az Origo általános közéleti lap, de azért abban is markáns az eltérés a tantervi előfordulásokhoz képest a társadalomföldrajz javára.

Ezt követően a fogalmakat tovább bontottam az elsődleges tantervi témakörök szerint (2. táblázat). A továbbiakban ezeket a fó témaköröket elemzem alcsoportjaik szerint. Az általános természetföldrajz témaköreiben mindegyiknek alacsonyabb a média-megjelenése, mint a tantervben. Egyetlen kivételt a rokontudományokhoz kapcsolódó csillagászati földrajz képez, ahol a magas előfordulási arány elsősorban a médiában előforduló ürkutatási programoknak, csillagászati megfigyelésekről való tudósításoknak köszönhető.

A globális problémák - feltételezésem ellenére - messze nem tartoztak a populáris témakörök közé a médiában. DALELO, A. (2011) globális éghajlatváltozáshoz kapcsolódó

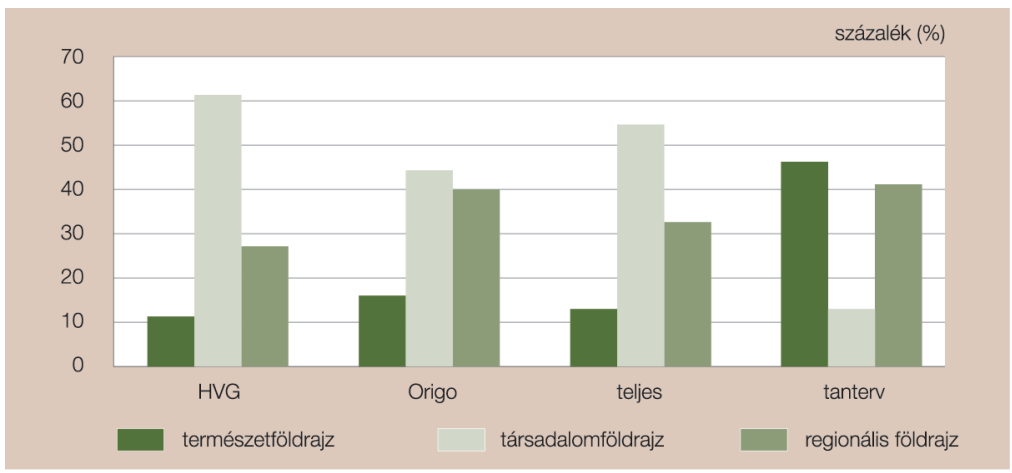

1. ábra. A médiából származó minta három fóág szerinti megoszlása (\%) 
etiópiai tantervi vizsgálatai során azt a nálunk is érvényesnek tekinthető következtetést vonta le, hogy a tanterv ugyan lehetőséget biztosít az éghajlatváltozás külön oktatási anyagot és időt nem igénylő integrálására, azonban a tartalmi, szemléleti és eszközbeli hiányosságok akadályozzák a problémakör megértését. A tanterv pedig kevés időt és lehetőséget ad a tanulóknak, hogy a gyakorlatban is hozzájáruljanak a környezeti hatások csökkentéséhez, holott ez alapvetően befolyásolja az emberiség jövőjét.

A természetföldrajzi fogalmak fele a felszínalaktanhoz tartozik, amely témakör önállóan nem jelenik meg a Kerettantervben, hiszen a különböző geoszférákhoz kapcsoltan beszélünk felszínalaktani formákról. A második legmagasabb témaköri elöfordulást a csillagászati földrajz után a vízburok fogalmai érték el, miközben egy mérőlapos vizsgálat alkalmával kiderült, hogy a mérőlapot kitöltő több mint 2000 fő szerint az a legkevésbé kedvelt és hasznos témakörök közé sorolható (Номокі E. 2016).

A társadalomföldrajz témakörei között általános társadalom- és gazdaságföldrajzból mutatkozik a legnagyobb eltérés a tantervhez képest (2. táblázat), mint ahogy egy finn tankönyvelemzés (TANI, S. 2004) is hasonló eredményre jutott. Ebben az eloszlásban megmutatkozik a HVG gazdasági jellege. A belső arányok is eltérnek a tantervtől. Az általános társadalmi, gazdasági folyamatok ismerete sokkal erőteljesebben jelentkezik, mint a regionális. A publikációs keretek ugyan nem teszik lehetővé a fogalmak listájának közlését (több mint $7000 \mathrm{db}$ ), de oktatási műhelymunkában ezek is felhasználhatók a tervezéshez. Néhány fogalom e témakörben: gazdasági, nemzetközi, állam, orosz, német, rt, kft, cég stb. A népesség- és településföldrajz arányai is - $10 \%$-os eltérést mutatnak a médiamegjelenés javára. Célszerü lenne a jelenlegi külpolitikai folyamatok jobb megértése végett e témakör közoktatási tartalmát felülvizsgálni, és az általános folyamatokon túl esettanulmányokat is megvizsgálni a ma igen nehéz helyzetben lévő országok szemszögéből.

A regionális fogalmak arányai mutatják a legkisebb eltérést a tanterv és a média között (2. táblázat). Az ide sorolt földrajzi nevek másodlagosan a természet- vagy társadalomföldrajzhoz, esetleg mindkettőhöz kapcsolódnak. Mivel a településeket, országokat a szövegkörnyezet vizsgálata nélkül a társadalomföldrajz témakörbe soroltam, ezért egyértelmü, hogy a média-megjelenés ennél a témakörnél részben túlreprezentált. A teljes mintában arányuk 83,8\% (HVG: 81,9\%; Origó: 85,77\%). Ha a regionális fogalmakat szétosztjuk másodlagos témakörük szerint az elsődleges földrajzi ágak között, a földtudományi-természetföldrajzi és a társadalomföldrajzi-gazdasági fogalmi arány 18,2\%:81,4\%-ra módosul, ami utóbbi abszolút túlsúlyát jelenti. 


\begin{tabular}{|c|c|c|c|c|c|}
\hline Témakörök & $\begin{array}{l}\text { Tanterv } \\
(\%)\end{array}$ & $\begin{array}{l}\text { HVG } \\
(\%)\end{array}$ & $\begin{array}{l}\text { Origo } \\
(\%)\end{array}$ & $\begin{array}{l}\text { Teljes } \\
\text { minta } \\
(\%)\end{array}$ & $\begin{array}{l}\text { Eltérés } \\
\text { a médiában } \\
\text { a tantervtől }\end{array}$ \\
\hline Térképészet & 3 & 0,52 & 0,7 & 0,60 & $-2,40$ \\
\hline Csillagászati földrajz & 4 & 5,50 & 6,8 & 6,04 & 2,04 \\
\hline Földtan, talajtan & 9 & 0,99 & 1,24 & 1,10 & $-7,90$ \\
\hline Légkör, időjárás & 6 & 0,83 & 2,35 & 1,45 & $-4,55$ \\
\hline Vízburok, jég, karszt & 6 & 2,31 & 3,16 & 2,63 & $-3,37$ \\
\hline Földrajzi övezetesség & 6 & 0,69 & 0,91 & 0,78 & $-5,22$ \\
\hline Globális problémák & 7 & 1,22 & 1,26 & 1,23 & $-5,77$ \\
\hline Népesség- és településföldrajz & 5 & 14,28 & 16,94 & 15,38 & 10,38 \\
\hline Általános gazdaságföldrajz, közgazdasági ismeretek & 8 & 46,09 & 26,57 & 38,27 & 30,27 \\
\hline Magyarország, Kárpát-medence & 16 & 15,23 & 20,26 & 17,35 & 1,35 \\
\hline Európa (természet- és társadalomföldrajz) & 14 & 12,74 & 20,57 & 15,83 & 1,83 \\
\hline Európán kívüli világ (természet- és társadalomföldrajz) & 16 & 11,15 & 14,97 & 12,62 & $-3,38$ \\
\hline
\end{tabular}

2. táblázat. A médiából gyüjtött fogalmak tantervi témakörök szerinti gyakorisága

\section{Térbeliség megjelenése a fogalmak között}

Feltételeztem, hogy a médiában megjelenő földrajzi fogalmak arányai visszatükrözik majd hazánk gazdasági-politikai kapcsolatait. Ennek igazolására a regionális fogalmak közül a települések és városrészek halmaza alapján pontsürüségi térképet készítettem (Hомокі E. et al. 2017). A médiamegjelenés gyakorisági térképe nemcsak a centrum-periféria térségek globális eloszlását, hanem a regionális szintet is visszatükrözte. Természetesen a hatás kölcsönös, azaz a centrumtérségek jelentéktelenebb eseményei is jobban eladhatók, mint a kevésbé ismert helyeken történtek, ami hozzájárul a gyakoriság növekedéséhez. Összesen 225 ország szerepelt a listán önállóan vagy települése révén. A regionális fogalmakon belül abszolút többséget alkotnak az európai térségre vonatkozóak (71,70\%, a teljes minta 33,16\%a). A térbeli eloszlás további rajzolata Dél-Amerika, Afrika, illetve Ausztrália kisebb súlyát, Európa mellett Észak-Amerika és Kelet-Ázsia jelentős szerepét mutatják (2., 3. ábra).

A városok közül (6200) egyértelmű New York vezető szerepe a világban (5,51\%), amelyet Moszkva és London követ (3,09\%), 2\%-ot ért el Washington és Los Angeles, valamint Brüsszel. Ezután Európa fó és nagyvárosai következtek Bécs, Párizs, Madrid, Berlin, Barcelona, Róma, Manchester és - némi meglepetésre - csak egyetlen ázsiai város, Peking. Érdekes módon hazánk közvetlen szomszédjai sem jelentek meg annyiszor, hogy gyakoriságuk alapján az élmezőnybe tartozzanak. 

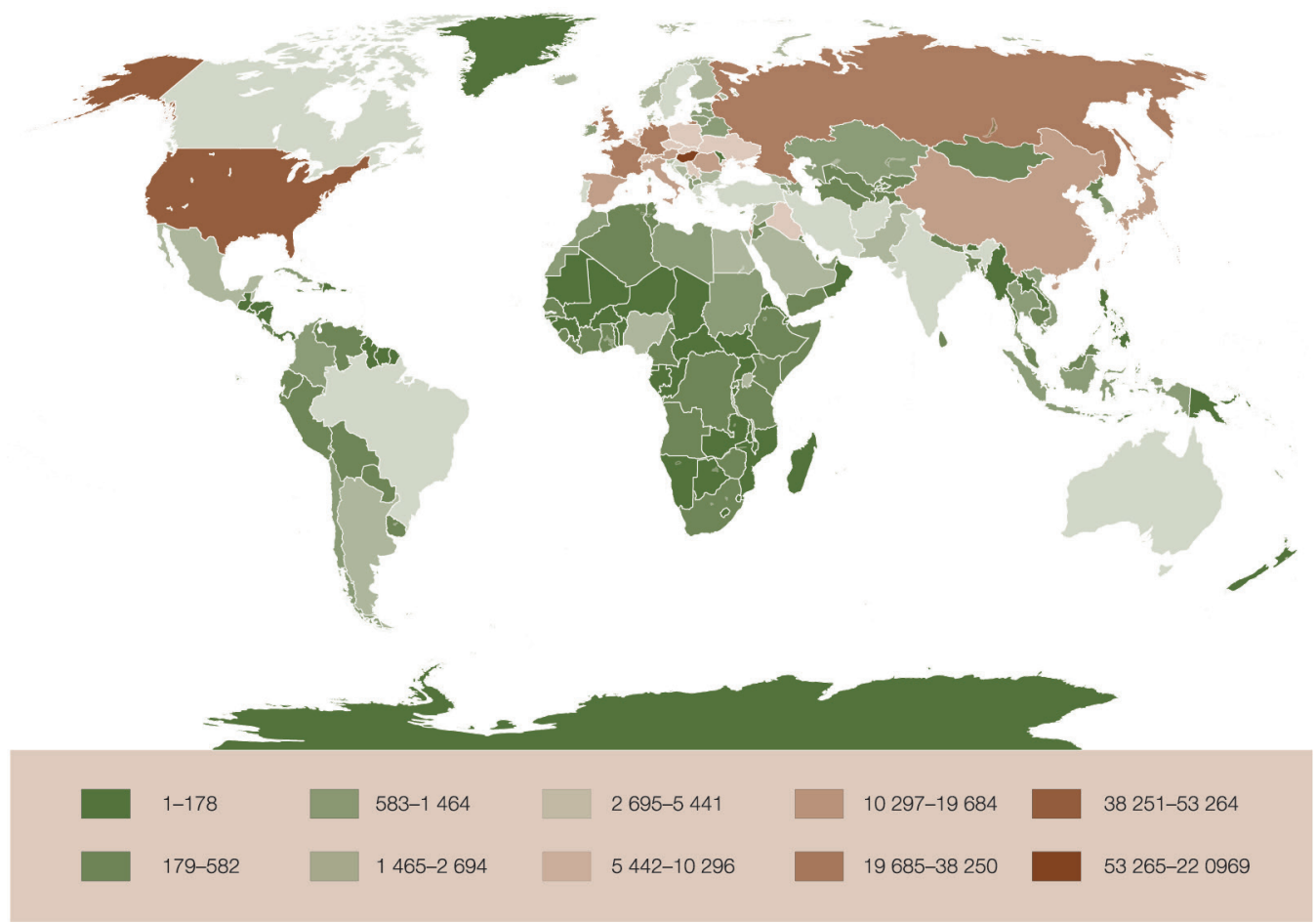

2. ábra. Az országokhoz köthetö földrajzi fogalmak gyakorisága (elöfordulások száma)

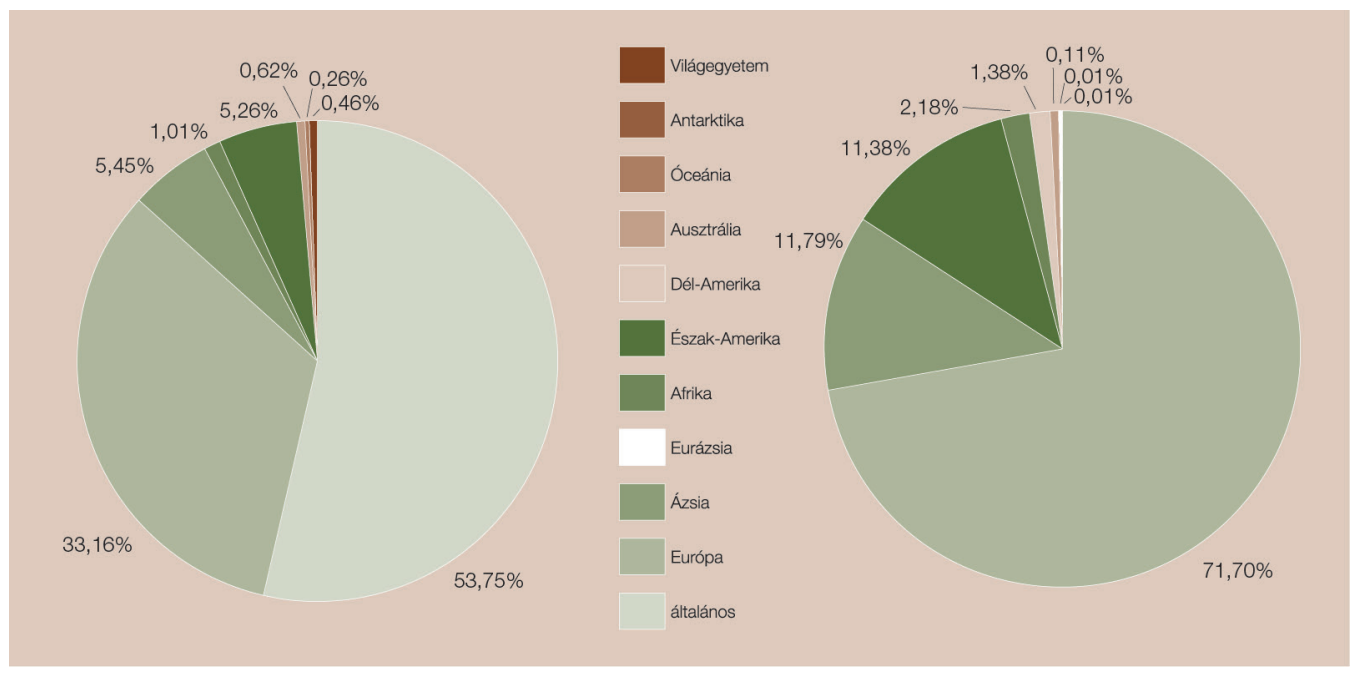

3. ábra. A médiából származó minta kontinensek szerinti abszolút száma és aránya (\%) 
Az elvárásoknak megfelelően Európán belül Magyarország relatív súlya emelhető ki $(39,63 \%)$. A természetföldrajzi fogalmak aránya alacsonyabb (8000) a társadalomföldrajzihoz képest (több mint 100 000). A tájföldrajzi gyakoriságot illetően elsődlegesen a turisztikai jelentőség, másodsorban az árvíz által érintett térségek tükröződnek vissza (4. ábra). A Balaton a legmagasabb előfordulási gyakoriságú (17,11\%), amelyet a Duna menti-síkság (9,89\%) és Budapest turisztikai látványosságai (például a Margitsziget) követnek, a továbbiakban pedig 6-6\% körüli aránnyal a Bakonyvidék, Sopron-Vasisíkság, Felső-Tisza-vidék, Tokaj-Zempléni-hegyvidék és az Észak-magyarországimedencék középtájak következnek.

A magyarországi települések eloszlásában egyértelmü Budapest központi szerepe (12,36\%). A megjelenési gyakoriságban is látható a túlméretezett szerepkör, mert utána csak nagyságrendileg elmaradva jelennek meg a régióközpontok 2-3\% közötti aránynyal, mint Debrecen, Győr, Szeged és Pécs. Miskolc, Székesfehérvár és Veszprém 1-2\%

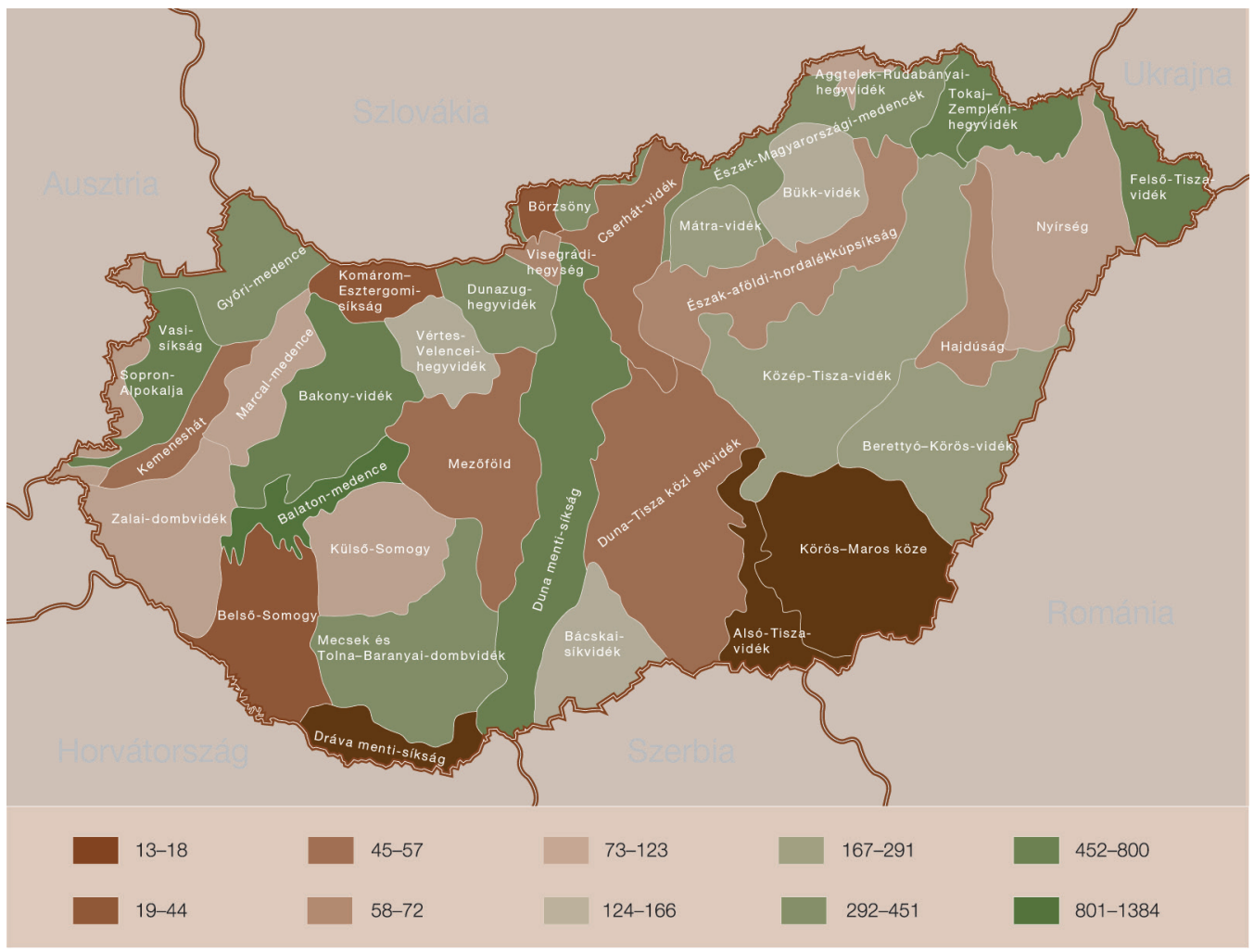

4. ábra. Természetföldrajzi fogalmak emlitésének megoszlása hazai középtájanként 
közötti értékkel ettől is elmarad, miközben más települések megelőzik azokat. A többi megyeszékhely előfordulása már nem éri el az 1\%-ot, a 0,1\% feletti arányt pedig csak 142 település (az összes 7\%-a) hozott a 2078 közül (Номокі E. 2016). A kisebb települések hírei, ha jelentősek is, csak rövid ideig maradnak médiafelületen.

A kontinensen második helyen Németország jelent meg, de nem az általam elvárt mértékben, hanem attól egy nagyságrenddel elmaradva (6,86\%), majd az Egyesült Királyság (5,19\%) és Oroszország következett $(5,14 \%)$. Európán belül a peremtérségek pontsűrüsége (Skandinávia, Baltikum, Írország, Portugália stb.) lényegesen alatta marad a vezető térségeknek (Номокі Е. 2016). Ha az egyszeres előfordulási értéket mutató településeket levesszük a térképről, jól kirajzolódik a „kék banán” területe. Oroszország magas médiaaránya (és a cikkek tartalma) visszatükrözi a politikai erőtérben elfoglalt helyét, elsősorban az Európához tartozó települések gyakorisága, valamint a politikai válsággócok (például csecsenföldi konfliktus) által.

Észak-Amerikában egyértelmű az Amerikai Egyesült Államok elsődleges szerepe (60,22\%), mely abszolút gyakoriságát tekintve hazánk mögöttáll. Ázsiában pedig Kína $(12,92 \%)$, Japán $(9,92 \%)$ és India $(4,36 \%)$ mellett a délnyugat-ázsiai térség országai is a rangsor elején szerepelnek, amit a pontsürüségi térkép is jól mutat (НомокI E. 2016). Észak-Amerika esetében a keleti part felülreprezentáltsága egyértelműen látszik, még a nyugati parthoz képest is, az euroatlanti kapcsolatoknak megfelelően. Ezt mutatja részben a három legfontosabb amerikai egyesült államokbeli nagyváros - New York, Washington, Los Angeles - jelentős együttes aránya (9,52\%), sőt Hollywood önmagában is eléri a 0,47\%-ot. Ahogy az országok arányaiból is kitünik, Afrika, Ausztrália és Dél-Amerika települései kisebb részt képviselnek, általában a part menti, kereskedelemben és gazdaságban egyaránt jelentősebb szerepet betöltő térségek, valamint a belső konfliktuszónák fordulnak elő. Az aktuális események (például a fukushimai tragédia) nagyobb számú megjelenése mellett Kína esetében a kelet-délkeleti országrész (Peking, Sanghaj, Hongkong, Sencsen), Japánban Tokió után a két nagy gazdasági gócpont (Yokohama, Osaka, Kyoto), Indiában a Gangesz völgye és a Himalája térsége mellett a fôváros és egy-egy gazdasági csomópont (Delhi, Mumbai) emelkedik ki. Bár az Európán kívüli kontinensek esetében mutatkozott némi többlet a tantervben a médiához képest (2. táblázat), de úgy vélem, ezen az arányon nem kellene változtatni, viszont jó lenne, ha a fontosabb topográfiai nevek a tantervben is visszaköszönnének. 


\section{Következtetések}

A tartalomelemzés során megállapítottam, hogy a médiában megjelenő fogalmak arányai jelentősen eltérnek a földrajz tantervi arányaitól. A kigyüjtött fogalmak 57,5\%-a szerepel a 2012-es Kerettantervben, a topográfiai névanyagnak pedig 59,5\%-a fordul elö az érettségi topográfiai névanyagban. Így $40 \%$ azok aránya, amelyeket önállóan kellene megtanulnia az olvasónak a hírek értelmezéséhez, ami csak biztos háttértudás birtokában müködhetne. A tantárgyi óraszámok és megbecsültség nem tükrözik vissza a jelentősnek tekinthető előfordulási gyakoriságot. Joggal feltételezhető, hogyha az olvasott szövegek 10\%-a a földrajzhoz és más földtudományokhoz kapcsolódik, miközben a tantárgyra jó esetben is csak 4\%-os keret jut - tudva, hogy a két arány egymással nem azonos tartalmú -, akkor a nemzetközi mérések alkalmával bizonyítottan fennálló szövegértési problémákat ez is komolyan befolyásolhatja.

Különböző szakos tanárok munkamegbeszélésein gyakran elhangzik segítő szándékkal a nagyobb óraszámú tárgyak képviselöitől, hogy az általuk gyakorolt szövegfeldolgozás hozzájárul a kevesebbet tanított szakterületek megértéséhez is. Ez azonban csak részben igaz, az általános szövegértés fejlesztése nem váltja ki a szakmai alapú ismeretátadást, hiszen a nem szakos képzettségủ pedagógus jó szándékkal is félremagyarázhat egyes fogalmakat, vagy csak egyszerủen nem hangsúlyozza azokat. Ugyanakkor a tanítói és óvodapedagógusi képzésbe vagy továbbképzésbe szakmai alapon bevezethető lenne a korosztálynak megfelelő földrajzi ismeretfeldolgozás, például kirándulások, mesék által (MATEsz K. 2011).

A médiából gyüjtött fogalmak besorolása során megvizsgáltam, hogy melyek azok, amelyek nincsenek benne a kerettantervben, de gyakoriságuk függvényében megfelelő szakmai egyeztetés után bekerülhetnének oda. A válogatás alapját a gyakorisági értékek adják, melyek meghaladják a témakörön belüli 0,5\%-ot (3. táblázat). Úgy gondolom, a kulcsfogalmak aktualizálásának rendszeres feladatnak kellene lennie. A kerettantervi rendszerező fogalmak mellett konkrét javaslatokkal lehetne a meglévőket rendszeresen pontosítani vagy legalább utalni arra, hogy a fogalomkör aktualizálását az információs társadalom gyors változásai miatt a helyi tantervben rendszeresen elvégezzék. Véleményem szerint ugyanis, ha a föbb oktatási dokumentumokban a kulcsfogalmak között felsoroljuk a köznapi információk megértéséhez szükségeseket, akkor csökkentjük azok tanítása során a szubjektív paramétereket, mint például a pedagógus beállítódásának, felkészültségének és műveltségének szerepét. Ha ezeket legalább a helyi tantervhez ajánlott módon konkretizáljuk, akkor felhívjuk a figyelmet a témakörre, 
elősegítve ezek órai használatát. Ez azért is egyre fontosabb feladat, mert a képesítés nélküli tanárok száma már most is, de az elkövetkező években még inkább növekedni fog, így munkájukat ezzel könnyíthetnénk meg.

A földtudományok-természetföldrajz oktatási oldalról túlreprezentáltnak tünik a médiaelőfordulás alapján, de a belső arányai (média és tanterv) inkább közelebb állnak egymáshoz, mint a társadalomföldrajz és a regionális kategóriáké (4. táblázat). Az eltérések alapján társadalomföldrajzi oldalról a gazdaságföldrajzi, közgazdasági és politikai földrajzi rész kíván erőteljes átgondolást. A népesség- és településföldrajzi témakörbe sorolt fogalmak használata közelebb áll a tananyaghoz, de tartalmi oldalról jobban

\begin{tabular}{|c|c|}
\hline Témakörök & Fogalmak \\
\hline Csillagászati földrajz & $\begin{array}{l}\text { égbolt, NASA, pólus, zenit, űrállomás (MIR), Apolló-program, aszteroida, } \\
\text { Greenwich, óriásbolygó, űrtávcső, csillagvizsgáló }\end{array}$ \\
\hline Térképészet & tér, sark, horizont, zóna, kartográfia \\
\hline Földtan, kőzetburok & arany, ezüst, lelőhely, kráter, földrész, szilícium, kristály, fosszília, anomália \\
\hline Talajföldrajz & $\begin{array}{l}\text { talajnedvesség, talajminta, termőképesség, talajcsere, szikes, termelékeny, } \\
\text { termőréteg, talajkeverék }\end{array}$ \\
\hline Légkör & vihar, derült, visszhang, hőség, OMSZ, oxigén, ultraibolya, zápor \\
\hline Vízburok & forrás, öböl, áradás, patak, apad(ás), vízszint, tározó, árhullám, elárasztás \\
\hline Felszínalaktan & $\begin{array}{l}\text { sziget, hát, csúcs, felszín, puszta, szoros, medence, völgy, tengerpart, } \\
\text { hegyi, süllyedő, tető, barlang, félsziget, meredek, meder, szakadék, lejtő, } \\
\text { gát, áttörés, szikla, hegyvidék, hegység }\end{array}$ \\
\hline Övezetesség & élőhely, dzsungel, land (táj) \\
\hline Globális problémák & környezetvédelem, védettség, zaj(os), világörökség, bioüzemanyag \\
\hline Népességföldrajz & $\begin{array}{l}\text { zsidó, roma, arab, amerikai, belga, dán, keresztény, portugál, palesztin, } \\
\text { kurd, iszlamista (tehát alapvetően a nemzetiségi és kulturális sokszínűség) }\end{array}$ \\
\hline Településföldrajz & székhely, nagyváros, városháza, község, kisváros, városvezetés \\
\hline Politikai földrajz & $\begin{array}{l}\text { állam, kormány, parlament, önkormányzat, külföld, megye, kormányfő, ha- } \\
\text { tár, országgyülés, tartomány, régió, NATO, köztársaság, regionális, vidék, } \\
\text { belföld, vidékfejlesztés, járás, jogállam, monarchia, területfejlesztés }\end{array}$ \\
\hline Gazdaságföldrajz & $\begin{array}{l}\text { Kft, Rt, dollár(os), bank, Zrt, növekedés, részvény, beruházás, privatizáció, } \\
\text { vállalkozó, MNB, holding, export }\end{array}$ \\
\hline Ágazati földrajz & $\begin{array}{l}\text { MOL, OTP, repülőtér, távközlés, légitársaság, MÁV, Malév, Ford, útvonal, } \\
\text { turista, üzemanyag, Dunaferr, Mercedes, Windows, közút, Ferrari, metró, } \\
\text { Richter, Opel, Volkswagen, Renault, üzletág, kitermelés, vízügy, gát, Pick, } \\
\text { külkereskedelem, Sony }\end{array}$ \\
\hline Regionális természetföldrajz & Ciprus, pannon \\
\hline Regionális társadalomföldrajz & Palesztina, Brüsszel, Bécs, Békéscsaba, Madrid \\
\hline
\end{tabular}

3. táblázat. Válogatás a médiában leggyakrabban használt, nem kerettantervi fogalmakból 
köthető lenne a klasszikus rendszertani szemlélet helyett az aktuális népesedési, települési kérdések alátámasztásához, a folyamatok megértéséhez

Egy konkrét példát kiemelve a népességcsoportok közül: nincsenek a tantervben az etnikailag problémás területek kulcsfogalmai, mint például szír, Gáza, Palesztina stb. Viszont így a híreket, $s$ az általuk közvetített társadalmi problémákat a tanulók nem értik meg felnőttként sem. A csak részben megértett információk birtokában, téveszmék által könnyebben átverhetők az emberek. Úgy vélem, hogy a földrajz egyik fö feladata napjainkban a toleranciára nevelés, amelyhez ez a témakör is fontos eszközként szolgálhat. Ehhez TANI, S. (2004) más népcsoportok, vallások és kultúrák részletesebb tanítását javasolta az elméleti népesség- és településföldrajzi fogalmak és folyamatok oktatása helyett. Véleményem szerint a témakör a globális problémák között is markánsabban megjelenhet, erősítve az egyes részterületek közötti szintézist. Valójában sosem volt oktatási szempontból fajsúlyos rész az etnikai és vallási földrajzi témakör, de az aktuális centrum-periféria viszonyok, válsággócok problémáinak megértéséhez erőteljesebb megjelenítésük szükséges lehet.

\begin{tabular}{|c|c|c|c|c|c|}
\hline & Tantervi témakör & $\begin{array}{l}\text { Nincs benne* } \\
\text { (db) }\end{array}$ & $\begin{array}{l}\text { Teljes minta } \\
\text { (db) }\end{array}$ & $\begin{array}{l}\text { Hiányzik a } \\
\text { tantervbőll (\%) }\end{array}$ & $\begin{array}{l}\text { Átlag } \\
\text { (\%) }\end{array}$ \\
\hline \multirow{9}{*}{$\begin{array}{l}\text { Természetföldrajz } \\
\text { és földtudományok }\end{array}$} & Csillagászati földrajz & 7657 & 101611 & 7,54 & \multirow[t]{9}{*}{28,47} \\
\hline & Térképészet & 2700 & 10027 & 26,93 & \\
\hline & Kőzetburok & 6661 & 17594 & 37,86 & \\
\hline & Talajföldrajz & 154 & 808 & 19,06 & \\
\hline & Légkör & 5348 & 24339 & 21,97 & \\
\hline & Vízburok & 8025 & 21245 & 37,77 & \\
\hline & Geomorfológia & 18208 & 23096 & 78,84 & \\
\hline & $\begin{array}{l}\text { Globális problémák, } \\
\text { környezetvédelem }\end{array}$ & 3963 & 20617 & 19,22 & \\
\hline & $\begin{array}{l}\text { Övezetesség, táj- és } \\
\text { életföldrajz }\end{array}$ & 924 & 13112 & 7,05 & \\
\hline \multirow[t]{5}{*}{ Társadalomföldrajz } & Népességföldrajz & 49694 & 222677 & 22,32 & \multirow[t]{5}{*}{39,59} \\
\hline & Településföldrajz & 7036 & 35952 & 19,57 & \\
\hline & Politikai földrajz & 104705 & 196315 & 53,34 & \\
\hline & Gazdaságföldrajz & 149147 & 328414 & 45,41 & \\
\hline & Ágazati földrajz & 68062 & 118756 & 57,31 & \\
\hline \multirow[t]{2}{*}{ Regionális földrajz } & Természetföldrajz & 36227 & 87953 & 41,19 & \multirow[t]{2}{*}{47,42} \\
\hline & Társadalomföldrajz & 244653 & 456008 & 53,65 & \\
\hline
\end{tabular}

*nincs az érvényben lévő tanervi kulcsfogalmak között

4. táblázat. A fogalmak előfordulásának a tantervtől való eltérési értékei 
Javíthat a tantárgy megítélésén, ha a tantervben megjelenő új tartalmak szélesebb körben ismertek lesznek a közvélemény előtt, a már klasszikus ismeretelemek pedig más megvilágításba helyeződnek. A módszertani kínálatban szélesebb körben válnak használatossá az internetes és a mobil információszerzési és -feldolgozási elemek. A természetföldrajzban ilyen lehet a geoszférák használata (természeti erőforrások), a környezeti ártalmak, szennyezések és ezek hatásainak bemutatása (ÜTőNÉ VISI J. 2009), amelyhez a szakmai adatbázisok (pl. OMSZ, MFGI honlapja) is felhasználhatók. Társadalmi oldalról a közgazdasági alapfolyamatok és fogalmak, a globális változások kifejezetten földrajzosokhoz köthető értelmezése (ÜTőNÉ VISI J. 2009), valamint a társadalmi tér újraalkotása kapcsolható. A klasszikusnak számító regionális földrajzi tartalmak a világgazdaságban betöltött szerep alapján kerülhetnek feldolgozásra, aminek középpontjában inkább hasonló kultúrájú és gazdasági jellegü térségek, országcsoportok állnak.

A szemléletváltás mellett fontos az oktatási környezet (labor, kirándulások stb.) megszervezése is. Ha a tantárgyat illetően tíz év alatt még a földrajz szakos hallgatók körében is pozícióvesztés következett be (Номокі E. 2016), akkor fennáll a veszélye a tantárgyi létjogosultság elvesztésének. Ismereteinek feldarabolását elősegítheti - a társadalmi nyomásnak engedve - a közgazdaságtanhoz, környezettanhoz kapcsolódó tanárszakok megjelenése. Véleményem szerint ezzel éppen ellentétes oktatáspolitikai célt kellene megvalósítani, hogy a középiskolában az integrált tárgyak (mint a földrajz is) minél több kapcsolódó felsőoktatási szakon (közgazdasági képzések, környezetmérnök stb.) bemeneti tárgy legyen. Figyelembe lehetne venni azt is, hogy a sporttól a valláson át a családtól átvett köznapi ismeretekig terjedően azokat a tantárgyi elemeket, amelyek több országban teljesen más közoktatási területeken - szakkörök, képzőkörök, iskolai szabadidős elfoglaltságok keretében jelennek meg, nálunk se a tantárgyak rovására kerüljenek az oktatási keretbe. Hiszen ezek elsődleges célja nem az ismeretátadás, hanem az életmódhoz kötődő minták átadása lenne, amelyek kötetlenebb, de kötelező formában valószínüleg sikeresebben töltenék be funkciójukat. Ami az általános óraszámcsökkenés mellett a kis óraszámú természettudományos (a földrajzot is beleértve) tantárgyak esetén módot adhatna korrekcióra, miközben az egész napos iskolai felügyeletet is hasznosabban valósíthatná meg.

A fentiek szellemében elengedhetetlennek tartom, hogy a Nemzeti alaptanterv következő felülvizsgálatánál a Földünk - környezetünk müveltségi terület a 11. évfolyamon is kapjon egy minimális időkeretet, ahogy ezt már az MTA Földrajzi Bizottságai Oktatási Albizottsága is megfogalmazta (SzABó J. et al. 2010). A földi környezet megismerése, a napjainkat átszövő erőforrás-szükséglet, valamint a környezeti problémák összetettsége 
miatt középiskolában szükség lenne még egy év oktatási keretre a 17-18 éves korosztály számára a hiányzó szintézis biztosításához. Minden évfolyamon kötelezően be kellene vezetni a heti két órát, már az alsó tagozatos környezetismeret tantárggyal kezdve. A tapasztalatok alapján nyugodtan kimondhatjuk, hogy egy tantárgy megbecsültségét az oktatási rendszerben az óraszáma is meghatározza. A kényszeresen felvételicentrikus társadalmi hozzáállás alapján pedig az a tantárgy, amelyik nem szerepel érettségin, alacsony az óraszáma, és nem is tanulják a közoktatás minden évfolyamán, az a szülők és a diákok számára - sőt időnként pedagógusoknak is - azt sugallja, hogy kevésbé fontos. Így viszont kontraszelekció indul meg a felsőoktatásban is.

Egyszerü lenne levonni azt a következtetést, hogy a társadalomföldrajzi tudás arányának növelésével átalakíthatók a tartalmi keretek. Azonban a média és a vélemények a társadalmi igényeknek csak egyik oldali lenyomatát adják. A társadalomföldrajzi tudáselemek mögött gyakran ott állnak azok a földtudományi háttérismeretek (például bányászat, mezőgazdaság, turizmus, környezetvédelem), amelyek nélkül földrajzi környezetünk nem müködtethető fenntarthatóan. Mint ahogy fordítva is igaz, a földtudományi ismeretek leginkább valamilyen társadalmi kontextusban (természeti érték, veszély, erőforrás, környezeti hatás stb.) jelennek meg. Bármelyik irányba toljuk el a tartalmak arányát a földtudományok, a természetföldrajz, a regionális földrajz vagy a társadalomföldrajz között, mindegyik ismeretátadása sérül. Az egymásra épülő, integrált tartalom miatt éppen a szintetizáló és aktualizáló szemlélete vész el. Ha a szűkebben értelmezett földtudomány közoktatási képviselet nélkül maradna, az negatívan hatna vissza a földrajztanári és geográfusképzésre is. Nemcsak a földtudományi, földrajzi szakma miatt, hanem mert a földi környezeti folyamatok társadalmi kapcsolatainak megértését, illetve - ha ez kissé talán patetikusan is hangzik - gyerekeink tudatos jövőbeni környezeti viszonyának kialakítását is veszélyeztetné.

\section{Irodalom}

Antal L. 1976: A tartalomelemzés alapjai. Magvető, Budapest. 152 p.

BABBIE, E. 2001: A társadalomtudományi kutatás gyakorlata. Balassi, Budapest. 744 p.

DALELo, A. 2011: Global climate change in geography curricula for Ethiopian secondary and preparatory schools. - International Research in Geographical and Environmental Education 20. 3. pp. $227-246$. doi:10.1080/10382046.2011.588505

Номокі E. 2016: Földrajzi ismeretek és készségek kapcsolata a hétköznapi élettel különböző társadalmi csoportok vizsgálata alapján. Doktori (PhD) értekezés. Debreceni Egyetem Földtudományi Doktori Iskola, Debrecen. 168. p. 
Номокі E.-Süтő L.-KонÁn B. 2017: Szövegelemzési eredmények megjelenítése geoinformatikai szoftverek alkalmazásával. In: BALÁzs B. (szerk.): Az elmélet és a gyakorlat találkozása a térinformatikában VIII. Térinformatikai Konferencia és Szakkiállítás. Debreceni Egyetemi Kiadó, Debrecen. pp. 153-161.

KrippendorfF, K. 2004: Content analysis. An introduction to its methodology. Sage, Beverly Hills. 413 p. Lengyelné Molnár T. 2011: Referátumkészítés. Eszterházy Károly Főiskola, Eger, 140 p.

Matesz K. 2011: Tér a mesében, mese a térben, turizmus és fikció. Doktori (PhD) értekezés. Pécsi Tudományegyetem, Pécs. $140 \mathrm{p}$.

MelLes K. 2009: NMA. Nyomtatott sajtó - mérlegen 2008. http://ipsos.hu/hu/news/nma-nyomtatott-sajto-merlegen-2008. Letöltve: 2014.12.28.

Sample Size Calculator 2012. http://www.surveysystem.com/sscalc.htm. Letöltve: 2013.07.12. http://www. raosoft.com/samplesize.html. Letöltve: 2013.07.20.

Szabó J.-KubA G.-Horváth G. (szerk.) 2010: A Magyar Földrajzi Társaság, a Földrajztanárok Egylete és az MTA X. Földtudományok Osztálya Földrajzoktatási Albizottsága állásfoglalása a magyarországi földrajzoktatás helyzetéről és a megoldandó feladatokról. Magyar Földrajzi Társaság; Földrajztanárok Egylete; MTA X. Földtudományok Osztálya Földrajzoktatási Albizottsága. Budapest. https://www.fazekas.hu/ munkakozossegek/foldrajz/allasfoglalas_2010_miniszteriumba-1.pdf. Letöltve: 2014.04.28.

Szuni A. 2014: A legnézettebb hazai weboldalak rangsora. http://ite.hu/legnezettebb-hazai-weboldalak-rangsora. Letöltve: 2015.01.15.

TANI, S. 2004: Curriculum reform and primary geography in Finland. A gap between theory and practice? - International Research in Geographical and Environmental Education 13. 1. pp. 6-20. doi:10.1080/10382040408668789

TerestyéNi T. 2008: A magyar, német, olasz és osztrák közszolgálati televíziós híradók összehasonlító elemzése. Jel-Kép 3. pp. 3-56.

ÜTŐNÉ VISI J. 2009: A földrajz tantárgy helyzete és fejlesztési feladatai. http://www.ofi.hu/tudastar/tantargyak-helyzete/foldrajz-tantargy. Letöltve: 2014.04.15.

Vofkori L. 2003: A földrajztudomány rendszertana. Pro-Print, Csíkszereda, 253 p.

100/1997. (VI. 13.) kormányrendelet az érettségi vizsga vizsgaszabályzatának kiadásáról. Magyar Közlöny 51. pp. 3866-3885.

110/2012. (VI. 4.) kormányrendelet a Nemzeti alaptanterv kiadásáról, bevezetéséről és alkalmazásáról. Magyar Közlöny 66. pp. 10635-10847.

169/2000. (IX. 29.) kormányrendelet az egyes tudományterületekhez tartozó tudományágak, valamint a művészeti ágak felsorolásáról. http://www.nefmi.gov.hu/letolt/felsoo/03mell2_tudagak_kormrend.pdf. Letöltve: 2014.04.26.

51/2012. (XII. 21.) EMMI rendelet a kerettantervek kiadásának és jóváhagyásának rendjéről. Magyar Közlöny 177. pp. 29870-29876. 